\title{
ANALISIS PERMINTAAN TELUR AYAM RAS \\ (Suatu Kasus di Kecamatan Seruyan Hilir \\ Kabupaten Kuala Pembuang Kalimantan Tengah)
}

\author{
Oleh: \\ TIRSA NEYATRI BANDRANG \\ Program Studi Ekonomi Pertanian Universitas Padjadjaran \\ Email: tirsaleihitu@gmail.com
}

\begin{abstract}
Abstrak
Penelitian dilakukan untuk mengidentifikasi faktor-faktor yang mempengaruhi permintaan telur ayam ras serta menganalisis tingkat elastisitas permintaan telur ayam ras di Kecamatan Seruyan Hilir. Hasil analisis menunjukkan bahwa secara simultan faktor yang mempengaruhi permintaan telur ayam ras meliputi harga telur ayam ras itu sendiri, harga ikan asin, harga ikan bandeng, pendapatan rumah tangga, jumlah anggota keluarga dan tingkat pendidikan ibu rumah tangga berpengaruh nyata terhadap variabel terikat yaitu permintaan telur ayam ras. Secara individual faktor harga telur ayam ras itu sendiri, harga ikan asin, harga beras, pendapatan rumah tangga dan jumlah anggota keluarga berpengaruh nyata terhadap permintaan telur ayam ras sedangkan untuk harga ikan bandeng dan tingkat pendidikan formal ibu rumah tangga tidak berpengaruh nyata terhadap variabel terikat. Tingkat elastisitas permintaan telur ayam ras di kecamatan Seruyan hilir, untuk elastisitas harga bersifat inelastis, dimana suatu kenaikan harga telur ayam ras akan menyebabkan perubahan jumlah yang diminta lebih kecil dari perubahan harga. Nilai koefisien elastisitas harga adalah $-0,175$. Untuk elastisitas silang untuk harga ikan asin dan harga beras adalah negatif yang merupakan barang komplementer (pelengkap) dan positif terhadap ikan bandeng yang merupakan barang substitusi (pengganti). Sedangkan elastisitas pendapatan adalah positif 0,843 menunjukkan bahwa permintaan telur ayam ras merupakan elastisitas pendapatan inelastis yang bersifat barang normal yaitu apabila telur ayam ras mengalami kenaikan dalam permintaan sebagai akibat dari kenaikan pendapatan.Berdasarkan hasil ini, disarankan bahwa upaya lebih lanjut untuk meningkatkan produksi telur ayam ras harus selalu dibuat dalam rangka memenuhi peningkatan kebutuhan konsumsi dan untuk mengejar standar yang ditetapkan oleh Pemerintah Kabupaten Seruyan.
\end{abstract}

Kata kunci: telur ayam, permintaan, elastisitas

\section{PENDAHULUAN}

Dalam pembangunan nasional Indonesia, sub sektor peternakan merupakan bagian dari sektor pertanian. Disadari atau tidak, sub sektor peternakan memiliki peranan yang sangat strategis dalam kehidupan perekonomian dan pembangunan sumber daya manusia Indonesia. Peranan ini dapat di lihat dari fungsi produk peternakan sebagai penyedia protein hewani yang penting bagi pertumbuhan dan perkembangan tubuh manusia. Oleh karenanya tidak mengherankan bila produk-produk peternakan disebut sebagai bahan "pembangun" dalam kehidupan ini.Selain itu peningkatan kesejahteraan masyarakat akan diikuti dengan peningkatan konsumsi produk-produk peternakan yang turut menggerakan perekonomian pada sub sektor peternakan.

Peningkatan sumber daya manusia tidak mungkin tercapai tanpa gizi yang cukup. Untuk mencerdaskan, memperkokoh dan meningkatkan prestasi manusia Indonesia banyak bergantung pada pemenuhan gizi yang baik terutama dari protein hewani seperti daging, susu dan telur. Usaha peternakan adalah usaha yang menghasilkan bahan pangan hewani yang memiliki nilai gizi yang tinggi. Telur merupakan salah satu produk peternakan yang dapat memenuhi sebagian kebutuhan gizi masyarakat. Nilai gizi dari telur inilah menyebabkan telur memiliki kelas di mata masyarakat Indonesia. Produk hasil ternak ini juga mempunyai potensi untuk dikembangkan secara optimal, karena di samping harganya yang relatif murah dibanding dengan protein hewani yang lainnya, pengusahaannya juga relatif mudah, walaupun di usahakan dalam usaha skala kecil mampu meningkatkan pendapatan dan memperluas kesempatan kerja.

Pertumbuhan ekonomi di berbagai sektor telah memacu peningkatan pendapatan masyarakat. Peningkatan pendapatan ini akan mempengaruhi kemampuan masyarakat untuk meningkatkan gizinya terutama yang bersumber 


\section{MIMBAR \\ A GRIBISNIS}

ISSN 2460-4321

Volume 1・ Nomor 1・Juli 2015

dari pangan hewani. Kondisi ekonomi masyarakat seperti ini relatif mudah diukur dan sangat besar pengaruhnya terhadap pola konsumsi pangan masyarakat. Salah satu sumber protein hewani untuk kebutuhan konsumsi adalah telur. Telur merupakan hasil ternak yang mempunyai peranan penting dalam mengatasi masalah gizi masyarakat. Konsumsi telur lebih besar daripada konsumsi hasil ternak lain. Hal ini dikarenakan telur merupakan komoditi yang mudah diperoleh serta harganya relatif murah dan terjangkau bagi masyarakat.

Berdasarkan keputusan Gubernur Kalimantan Tengah tentang sasaran populasi dan produksi pangan peternakan di Provinsi Kalimantan Tengah tahun 2011 untuk produksi pangan telur ayam ras tertinggi di Kalimantan Tengah berada pada daerah Kotawaringin Timur dan daerah Kapuas sedangkan pada tingkat terendah berada pada daerah Barito Selatan dan daerah Katingan. Untuk Kabupaten Seruyan produksi pangan peternakan yang paling banyak yaitu produksi telur ayam ras petelur mencapai $198.540 \mathrm{~kg}$ dibandingkan dengan produksi telur itik dan telur ayam buras yang tingkat produksinya tidak terlalu banyak, tingkat pencapaiannya berkisar $71.947 \mathrm{~kg}$ untuk telur itik dan $79.680 \mathrm{~kg}$ untuk telur ayam buras. Hal ini dikarenakan untuk komoditas pangan khususnya produksi telur masih didatangkan dari luar daerah, sehingga tingkat populasi dan produksi telur baik telur ayam ras, telur ayam buras, maupun telur itik persediaannya terbatas.

Tujuan penelitian yaitu:

1. Mengidentifikasi faktor-faktor yang mempengaruhi permintaan telur ayam ras di Kecamatan Seruyan Hilir.

2. Menganalisis tingkat elastisitas permintaan telur ayam ras di Kecamatan Seruyan Hilir.

\section{TINJAUAN PUSTAKA}

Dalam istilah ekonomi secara umum dikenal istilah Demand yang berarti permintaan. Menurut Soekartawi (2002), pengertian permintaan adalah jumlah barang yang sanggup dibeli oleh para pembeli pada tempat dan waktu tertentu dengan harga yang berlaku pada saat itu. Jumlah komoditas total yang ingin dibeli oleh semua rumah tangga disebut jumlah yang diminta (quantity demanded). Ada tiga hal yang harus diperhatikan dalam konsep ini, yaitu (Lipsey, et al, 1992) :
1. Jumlah yang diminta merupakan kuantitas yang diinginkan (desired

2. Apa yang diinginkan tidak merupakan harapan kosong, tetapi merupakan permintaan efektif,

3. Kuantitas yang diminta merupakan arus pembelian yang kontinyu.

Ada dua hal yang menjadi penyebab, yaitu: 1) adanya efek pendapatan, apabila harga suatu barang naik maka akan berpengaruh terhadap daya beli, 2) adanya efek substitusi, apabila harga suatu barang naik, sedang harga barang lain tetap, konsumen akan mencari atau berusaha mengganti barang yang lebih murah. Menurut Lipsey, et al (1992) Pergerakan dalam kurva permintaan dapat terjadi apabila hanya harga yang berubah, ceteris paribus sehingga perubahan jumlah yang diminta hanya terjadi sepanjang kurva permintaan. Namun jika yang mempengaruhi permintaan adalah faktor lain selain harga, dengan asumsi cateris paribus maka perubahan jumlah yang diminta akan menggeser kurva ke atas dan kebawah. Apabila pendapatan naik maka kurva permintaan bergeser sejajar ke kanan, tetapi sebaliknya apabila pendapatan turun maka kurva permintaan akan bergeser ke kiri.

Menurut Rasyaf, M (1991) menyatakan bahwa beberapa faktor yang mempengaruhi konsumsi telur adalah :

1. Pendapatan. Meningkatnya pendapatan masyarakat maka permintaan akan telur pun juga meningkat begitu pula sebaliknya. Pada harga tetap (ceteris paribus) maka jumlah yang diminta akan bertambah pula.

2. Selera dan rasa telur. Telur ayam ras mempunyai sifat spesifik untuk diolah menjadi bentuk lain yang tidak sama dengan telur unggas lainnya.

3. Jumlah konsumen ini sangat mempengaruhi permintaan telur apabila jumlah konsumen yang tinggi sangat potensial untuk peningkatan permintaan telur. Karena permintaan pasar diperoleh dari permintaan masing-masing individu.

4. Harga barang substitusi atau terkait. Ikan memiliki sifat yang spesifik sehingga dapat mensubstitusi. Misalnya harga telur naik maka konsumen akan beralih kepada jenis ikan atau daging demikian sebaliknya jika harga jenis ikan mengalami kenaikan harga maka permintaan akan ikan dan daging 
menurun dan konsumen akan beralih memilih telur.

Besarnya elastisitas dapat bervariasi antar nol hingga tak terhingga. Elastisitas sama dengan nol jika jumlah yang diminta tidak tanggap sama sekali terhadap perubahan harga. Selama persentase perubahan kuantitas lebih kecil daripada persentase perubahan harga, besarnya elastisitas permintaan akan lebih kecil dari satu. Jika kedua persentase perubahan tersebut sama dengan yang lainnya, maka elastisitasnya sama dengan satu. Jika persentase perubahan kuantitas melampaui persentase perubahan harga, nilai elastisitas permintaannya lebih besar daripada satu. Apabila persentase perubahan kuantitas lebih kecil daripada persentase perubahan harga (elastisitasnya kurang dari satu), permintaannya disebut bersifat inelastis. Sedangkan apabila persentase perubahan kuantitas lebih besar daripada persentase perubahan harganya (elastisitas lebih dari satu) permintaannya bersifat elastis (Lipsey, et al,1992).

\section{METODE PENELITIAN}

Penelitian akan dilakukan di Kecamatan Seruyan Hilir di empat desa/ kelurahan yaitu kelurahan Kuala Pembuang I sebanyak 134 sampel, kelurahan Kuala Pembuang II sebanyak 137 sampel, desa Tanjung Rangas sebanyak 58 sampel dan desa Sungai Undang sebanyak 45 sampel.Adapun waktu penelitian ini dilakukan dimulai dari persiapan hingga pengumpulan data, tabulasi, analisis sampai dengan penyusunan laporan penelitian yakni mulai pada bulan Maret sampai dengan bulan Juli 2012. Populasi (universe) dalam penelitian ini adalah ibu-ibu rumah tangga di Kecamatan Seruyan Hilir yang mengkonsumsi telur ayam ras. Sedangkan untuk mendapatkan sampel dapat menggunakan rumus Slovin (dalam Setiawan, 2007) yaitu sebagai berikut:

$$
n=\frac{N}{1+N \cdot e^{2}}
$$

Untuk mengetahui tujuan pertama dari penelitian ini, yakni bagaimana faktor- faktor yang mempengaruhi telur ayam ras di Kecamatan Seruyan Hilir digunakan model persamaan:

$L n Y=\ln a+b_{1} \ln x_{1}+b_{2} \ln x_{2}+b_{3} \ln x_{3}+b_{4} \ln$ $x_{4}+b_{5} \ln x_{5}+b_{6} \ln x_{6}+u$
Dimana;

Y: Jumlah telur yang diminta oleh rumah tangga per bulan (butir)

a : Intersep

bi : Koefisien regresi (elastisitas permintaan)

$\mathrm{x}_{1}$ : Harga telur ayam ras dalam rupiah per kilogram $(\mathrm{Rp} / \mathrm{kg})$

$\mathrm{x}_{2}$ : Harga ikan asin dalam rupiah per kilogram $(\mathrm{Rp} / \mathrm{kg})$

$\mathrm{x}_{3}$ : Harga ikan bandeng dalam rupiah per kilogram $(\mathrm{Rp} / \mathrm{kg})$

$\mathrm{x}_{4}$ : Harga beras dalam rupiah per kilogram $(\mathrm{Rp} / \mathrm{kg})$

$\mathrm{x}_{5}$ : Pendapatan rumah tangga (Rp/bulan)

$\mathrm{x}_{6}$ : Pendidikan ibu rumah tangga (tahun)

$\mathrm{x}_{7}$ : Jumlah anggota keluarga dalam satuan orang

$\mathrm{u}$ : $\quad$ Unsur sisa (peubah pengganggu)

\section{HASIL DAN PEMBAHASAN \\ Karakteristik responden}

Berdasarkan hasil survey di lapangan menunjukkan bahwa rata-rata umur responden khususnya ibu rumah tangga permintaan telur ayam ras tingkat rumah tangga di Kecamatan Seruyan Hilir berkisar antara 20 sampai dengan di atas 70 tahun dimana dalam penelitian ini umur responden yang terbesar berada pada kelompok umur 30-34 tahun dengan jumlah 97 orang atau $26 \%$ dan yang terkecil berada pada kelompok umur $\geq 70$ tahun (74 tahun ) yaitu berjumlah 1 orang atau $0 \%$. Artinya bahwa responden permintaan telur ayam ras tingkat rumah tangga di Kecamatan Seruyan Hilir, $100 \%$ masih termasuk kategori usia yang produktif dalam berpikir sehingga dalam menentukan pilihan atau keputusan mengkonsumsi telur ayam ras masih cenderung rasional.

Berdasarkan tingkat pendidikan formal banyaknya responden yang tidak tamat $\mathrm{SD} /$ sederajat dan yang tamat $\mathrm{SD} /$ sederajat yaitu mencapai $45 \%$, sedangkan responden yang berpendidikan tamat SLTP, tamat SLTA, tamat Diploma dan tamat Sarjana yaitu mencapai 55\%. Responden yang mempunyai tingkat pendidikan rendah (tidak tamat $\mathrm{SD} /$ sederajat, tamat SD/ Sederajat dan tamat SLTP) adalah responden yang berasal dari Desa Tanjung Rangas dan Sungai Undang. Sedangkan responden yang rata-rata mempunyai tingkat pendidikan cukup tinggi berasal dari Kelurahan Kuala Pembuang I dan Kuala Pembuang II. Adapun jumlah tanggungan pada penelitian ini yaitu sebanyak 374 responden memiliki jumlah 


\section{MIIMBAR \\ A GRIBISNIS \\ ISSN 2460-4321}

Volume $1 ・$ Nomor $1 ・$ Juli 2015

tanggungan responden terbanyak yaitu 2 tanggungan sebanyak 149 responden (40\%) sedangkan jumlah tanggungan terkecil yaitu 6 dan 9 tanggungan sebanyak 2 responden $(0,5 \%)$.

Begitu pun besarnya pendapatan rumah tangga responden telur ayam ras di daerah penelitian bervariasi yaitu hampir sebagian besar ibu rumah tangga tidak bekerja melainkan hanya mengurus rumah tangga, jumlah yang di peroleh sebanyak 165 orang atau berkisar 44,1 $\%$ dan besarnya pendapatan rata-rata yang diperoleh setiap rumah tangga responden yaitu berkisar Rp 1.000.000 - Rp 1.499.999 / bulan sebanyak 81 orang atau 21,65\% dari jumlah responden.

Faktor-Faktor yang Mempengaruhi Telur Ayam Ras Di Kecamatan Seruyan Hilir

Permintaan telur ayam ras dipengaruhi 4 faktor yaitu harga meliputi harga telur ayam ras itu sendiri $\left(\mathrm{X}_{1}\right)$, harga barang lain dalam hal ini ikan asin $\left(\mathrm{X}_{2}\right)$, ikan bandeng $\left(\mathrm{X}_{3}\right)$ dan harga beras $\left(\mathrm{X}_{4}\right)$, pendapatan rumah tangga $\left(\mathrm{X}_{5}\right)$, pendidikan IRT $\left(\mathrm{X}_{6}\right)$ serta jumlah anggota keluarga $\left(\mathrm{X}_{7}\right)$.

Untuk mengetahui seberapa besar pengaruh faktor-faktor tersebut terhadap permintaan telur ayam ras tingkat rumah tangga, maka dilakukan analisis regresi linier berganda dengan menggunakan tujuh variabel. Hasil analisis dengan menggunakan program computer Statical Package for the Sosial Sciences (SPSS) seperti pada Tabel 1. Dimana diperoleh:

Ln $\mathrm{Y}=-5,036-0,175 \operatorname{Ln} \mathrm{X}_{1^{-}}$0,070 Ln $\mathrm{X}_{2}+$ $0,042 \operatorname{Ln} X_{3}-0,293 \operatorname{Ln} X_{4}+0,843 \operatorname{Ln} X_{5}+$ $0,031 \mathrm{Ln} \mathrm{X}_{6}+0,087 \operatorname{Ln} \mathrm{X}_{7}+\mathrm{u}$

Pengujian dalam penelitian ini berpedoman pada pengujian model pengujian model dan pengujian asumsi klasik.

\section{Pengujian Model}

Nilai $\mathrm{R}^{2}$ yang disesuaikan sebesar 0,861 artinya bahwa perubahan variabel bebas mampu menjelaskan perubahan variabel terikat sebesar $86,1 \%$ sedangkan sisanya $13,9 \%$ adalah faktor lain di luar model persamaan. Hasil uji $\mathrm{F}$ dalam penelitian ini memiliki nilai $\mathrm{F}$ - hitung sebesar 330,176 dengan tingkat signifikansi yaitu nilai p sebesar 0,000 atau dapat diartikan nilai $\mathrm{p}<$ taraf nyata $5 \%$ yaitu 0,05 maka $\mathrm{H}_{\mathrm{o}}$ di tolak sedangkan $\mathrm{H}_{1}$ di terima artinya bahwa secara simultan variabel bebas yaitu harga telur ayam ras, harga ikan asin, harga ikan bandeng, pendapatan rumah tangga, pendidikan ibu rumah tangga dan jumlah anggota keluarga berpengaruh nyata terhadap variabel terikat yaitu permintaan telur ayam ras. Hasil analisis statistik fungsi permintaan telur ayam ras tingkat rumah tangga dapat dilihat pada Tabel 2.

Untuk mengetahui variabel apa saja yang secara statistik berpengaruh nyata terhadap perubahan permintaan telur ayam ras tingkat rumah tangga di Kecamatan Seruyan Hilir, maka dilakukan uji secara parsial menggunakan uji t. Dari Uji t dapat di lihat bahwa ada 5 variabel bebas dari 7 variabel bebas yang dianalisis yang berpengaruh nyata terhadap variabel terikat yaitu variabel harga telur ayam ras sendiri, harga ikan asin, harga beras, pendapatan dan jumlah anggota rumah tangga dengan nilai t- hitung peubah-peubah bebas tersebut memiliki nilai signifikansi $<0,05$.

Hasil analisis uji $t$ dapat dijelaskan sebagai berikut:

(1) Setiap kenaikan harga telur ayam ras sebesar 1 satuan (point) akan menurunkan permintaan telur ayam ras tingkat rumah tangga sebesar 0,175 satuan (point).

(2) Setiap kenaikan harga ikan asin yang merupakan barang komplementer dalam penelitian ini yaitu sebesar 1 satuan (point) akan menurunkan permintaan telur ayam ras tingkat rumah tangga sebesar 0,070 satuan (point).

(3) Setiap kenaikan harga beras yang juga merupakan barang komplementer atau barang pelengkap dalam penelitian ini yaitu sebesar 1 satuan (point) maka akan menurunkan permintaan telur ayam ras tingkat rumah tangga sebesar 0,293 satuan (point).

(4) Setiap kenaikan pendapatan rumah tangga sebesar 1 satuan (point) maka akan meningkatkan permintaan telur ayam ras tingkat rumah tangga sebesar 0,843 satuan (point).

(5) Setiap penambahan anggota rumah tangga sebesar 1 satuan (point) akan meningkatkan permintaan telur ayam ras tingkat rumah tangga sebesar 0,087 satuan (point). 
(6) Variabel harga ikan bandeng dan pendidikan ibu rumah tangga tidak berpengaruh nyata terhadap permintaan telur ayam ras tingkat rumah tangga.

Analisis mengenai pengaruh variabel bebas terhadap variabel terikat adalah sebagai berikut:

a. Harga telur ayam ras itu sendiri

Berdasarkan uji t, untuk harga telur ayam ras itu sendiri memiliki nilai $\mathrm{p}<$ taraf nyata 10 $\%$ atau $0,066<0,1$ sehingga dapat diartikan bahwa $\mathrm{H}_{0}$ ditolak dan $\mathrm{H}_{1}$ di terima pada taraf nyata $10 \%$. Koefisien regresi variabel harga telur ayam ras bertanda negatif artinya bahwa apabila harga telur ayam ras naik maka permintaan telur ayam ras tingkat rumah tangga akan turun atau sebaliknya apabila harga telur ayam ras turun maka permintaan telur ayam tingkat rumah tangga akan naik. Hal ini sesuai dengan hukum permintaan yaitu permintaan berbanding terbalik dengan harga.

b. Harga barang lain

Harga barang substitusi

Berdasarkan uji t, untuk harga ikan memiliki nilai $\mathrm{p}>$ taraf nyata $5 \%(0,544>$ 0,05)sehingga dapat diartikan bahwa $\mathrm{H}_{0}$ tidak dapat ditolak $\left(\mathrm{H}_{0}\right.$ diterima) pada taraf nyata $5 \%$. Perubahan harga ikan bandeng tidak berpengaruh nyata terhadap perubahan permintaan telur ayam ras tingkat rumah tangga. Karena sebagian responden tidak menyukai ikan bandeng serta banyaknya jenis ikan yang di konsumsi sehingga pergerakan harga ikan bandeng tidak mempengaruhi perubahan permintaan telur ayam ras. Nilai positif pada koefisien regresi menunjukkan bahwa ikan bandeng merupakan barang substitusi (pengganti) terhadap telur ayam ras.

\section{Harga barang komplementer}

Berdasarkan uji t, untuk harga ikan asin yang merupakan barang komplementer pertama dalam penelitian ini memiliki nilai $\mathrm{p}<$ taraf nyata $5 \%(0,029<0,05)$ sehingga dapat diartikan bahwa $\mathrm{H}_{0}$ ditolak dan $\mathrm{H}_{1}$ di teirma pada taraf nyata $5 \%$. Begitu pula dengan harga beras yang merupakan barang komplementer (barang pelengkap) memiliki nilai $\mathrm{p}<$ taraf nyata $5 \%(0,008<0,05)$ artinya bahwa $\mathrm{H}_{0}$ ditolak dan $\mathrm{H}_{1}$ diterima pada taraf nyata $5 \%$. Variabel harga ikan asin dan harga beras mempunyai hubungan yang negatif terhadap permintaan telur ayam ras. Artinya bahwa jika ikan asin dan harga beras naik akan menyebabkan jumlah permintaan ikan asin dan beras menurun sehingga menyebabkan konsumen mengurangi konsumsi telur ayam ras atau dengan kata lain permintaan telur ayam ras akan menurun pula.

Perubahan harga ikan asin dan harga beras berpengaruh nyata terhadap perubahan telur ayam ras. Nilai negatif pada koefisien regresi untuk harga ikan asin dan harga beras menunjukkan bahwa ikan asin dan beras merupakan barang komplementer (pelengkap). Hal ini dikarenakan sebagian besar konsumen menyukai ikan asin sebagai pelengkap lauk serta sebagian besar kebiasaan orang mengkonsumsi telur sebagai lauk pauk. Dengan demikian, permintaan telur ayam ras tingkat rumah tangga di Kecamatan Seruyan Hilir cenderung mengalami perubahan yang nyata terhadap harga ikan asin dan harga beras.

c. Tingkat pendapatan rumah tangga

Berdasarkan uji t, untuk tingkat pendapatan rumah tangga memiliki nilai $\mathrm{p}<$ taraf nyata $5 \%(0,000<0,05)$ sehingga dapat diartikan bahwa $\mathrm{H}_{0}$ ditolak dan $\mathrm{H}_{1}$ diterima pada taraf nyata $5 \%$. Hal ini berarti bahwa tingkat pendapatan rumah tangga secara statistik berpengaruh nyata terhadap permintaan telur ayam ras tingkat rumah tangga di Kecamatan Seruyan Hilir.

Koefisien regresi tingkat pendapatan rumah tangga sebesar 0,843 artinya apabila pendapatan meningkat sebesar 1 satuan (point) akan meningkatkan permintaan telur ayam ras tingkat rumah tangga sebesar 0,843 satuan (point). Dengan demikian, ada kecenderungan bahwa rumah tangga akan meningkatkan permintaan telur ayam ras bila pendapatan rumah tangga meningkat.

d. Tingkat pendidikan formal ibu rumah tangga

Berdasarkan uji t, untuk tingkat pendidikan formal ibu rumah tangga meiliki nilai $p>$ taraf nyata $5 \%(0,232>0,05)$ sehingga dapat diartikan bahwa $\mathrm{H}_{0}$ tidak dapat ditolak $\left(\mathrm{H}_{0}\right.$ diterima $)$ pada taraf nyata. Ini berarti bahwa tingkat pendidikan formal ibu rumah tangga secara statistik tidak berpengaruh nyata terhadap permintaan telur ayam ras. Hal ini dikarenakan tingkat 


\section{MIMBAR \\ A GRIBISNIS \\ ISSN 2460-4321}

Volume 1・Nomor 1・Juli 2015

pendidikan formal ibu rumah tangga di Kecamatan Seruyan Hilir yang lebih dominan adalah tamat SLTA artinya tingkat pendidikan pada kategori tamat SLTA memiliki kecenderungan untuk mengkonsumsi suatu barang lebih variatif dan kritis terutama berhubungan dengan pengetahuan tentang gizi dan kesehatan keluarga. Semakin tinggi tingkat pendidikan formal seorang ibu rumah tangga maka pengetahuan dalam mengkonsumsi barang pun lebih memadai dalam mengambil keputusan mengkonsumsi pangan.

\section{Pengujian asumsi klasik}

Untuk menguji kesalahan model regresi yang digunakan dalam penelitian, maka harus dilakukan pengujian asumsi klasik pada multikolineritas, autokorelasi dan heterokedastisitas.

Uji multikolinearitas dalam penelitian ini menunjukkan bahwa antar prediktor tidak mempunyai hubungan yang kuat. Hal ini dapat di lihat dari nilai VIF yang tidak melebihi nilai 10 sehingga dapat disimpulkan model tidak mengalami multikolinearitas dapat dilihat pada Tabel 3.

Uji autokorelasi Hasil pengujian menunjukkan bahwa nilai Durbin-Watson (DW) sebesar 1,287 atau berada diantara - 2,00 sampai $+2,00$. Dengan demikian, antar peubah bebas tidak terjadi autokorelasi.

Sedangkan Uji heterokedastisitas yaitu dengan menggunakan Scatter plot menunjukkan bahwa sebaran data tidak mengumpul di salah satu sudut plot dan tidak membentuk pola tertentu artinya tidak terjadi heterokedastisitas.

\section{Elastisitas Permintaan Telur Ayam Ras}

Elastisitas pada umumnya dinyatakan dalam persen (\%) atau nilai elastisitas itu sendiri yakni sama dengan nol, atau sama dengan satu atau juga tidak sama dengan nol maupun satu. Gambaran tentang nilai elastisitas menurut hasil analisis dapat dilihat pada Tabel4 1. Elastisitas harga

Nilai koefisien elastisitas harga telur ayam ras itu sendiri bernilai negatif yaitu sebesar 0,175 . Hal ini menunjukkan bahwa sesuai dengan hukum permintaan apabila terjadi kenaikan harga telur ayam ras, ceteris paribus akan diikuti penurunan permintaan jumlah telur ayam ras tingkat rumah tangga. Koefisien elastisitas harga telur ayam ras menunjukkan bahwa permintaan telur ayam ras bersifat responsif terhadap perubahan harga telur ayam ras itu sendiri. Perubahan harga telur ayam ras sebesar $1 \%$, akan menyebabkan perubahan permintaan telur ayam ras tingkat rumah tangga yaitu sebesar 0,175. Berdasarkan koefisien tersebut maka sifat permintaan telur ayam ras bersifat inelastik $(\mathrm{EP}<1)$, dimana apabila terjadi kenaikan harga terhadap telur ayam ras akan menyebabkan perubahan jumlah yang diminta lebih kecil dari perubahan harganya. Perubahan harga telur ayam ras hanya memberikan pengaruh kecil terhadap perubahan barang yang diminta, sehingga apabila terjadi kenaikan harga yang cukup tinggi sekalipun terhadap telur ayam ras, permintaan telur ayam ras tidak terlalu berubah.

2. Elastisitas silang

Elastisitas silang menunjukkan bahwa nilai elastisitas telur ayam ras terhadap ikan asin $($ Epx $=-0,070)$ dan beras $($ Epx $=-0,293)$ bertanda negatif sedangkan nilai elastisitas telur ayam ras terhadap ikan bandeng bertanda positif $(\mathrm{Epx}=0,042)$. Artinya apabila terjadi kenaikan harga ikan asin sebesar $1 \%$ maka akan menurunkan permintaan telur ayam ras tingkat rumah tangga sebesar 0,070 begitu pula dengan harga beras, apabila terjadi kenaikan harga beras sebesar $1 \%$ maka akan menurunkan telur ayam ras tingkat rumah tangga sebesar 0,293. Tetapi sebaliknya apabila terjadi kenaikan harga ikan bandeng sebesar 1 $\%$ maka akan terjadi kenaikan pula permintaan telur ayam ras tingkat rumah tangga. Apabila Epx positif maka elastisitas silang untuk komoditi substitusi karena harga satu komoditi dan komoditi lainnya bergerak dengan arah yang sama. Tetapi sebaliknya, apabila Epx negatif, maka elastisitas silang untuk komoditi komplementer karena harga dan jumlah yang diminta bergerak dengan arah yang berlawanan (Koutsoyiannis, 1979 dalam Imans, S, 2010).

Jumlah permintaan barang salah satunya ditentukan oleh kebiasaan atau budaya makan yang dimiliki masyarakat setempat. Dari hasil wawancara menunjukkan bahwa konsumen telur ayam ras juga mengkonsumsi ikan asin sebagai pelengkap lauk bukan sebagai bahan pengganti. Begitu pula dengan perubahan harga 
beras yang juga mempengaruhi permintaan telur ayam ras. Hal ini dikarenakan kebiasaan masyarakat dalam mengkonsumsi beras yang merupakan makanan pokok atau wajib, yang harus dikonsumsi sehingga harga beras tinggi mengakibatkan permintaan telur ayam ras menurun. Tetapi sebaliknya perubahan harga ikan bandeng tidak berpengaruh nyata terhadap permintaan telur ayam ras. Banyaknya jenis ikan yang tersedia serta faktor selera juga menjadi alasan konsumen untuk memilih berbagai macam ikan selain ikan bandeng.

\section{Elastisitas pendapatan}

Elastisitas pendapatan rumah tangga memiliki nilai $\mathrm{EI}=0,843$ menunjukkan bahwa permintaan telur ayan ras merupakan elastisitas pendapatan inelastis artinya perubahan pendapatan sebesar $1 \%$ menyebabkan perubahan permintaan kurang dari $1 \%$. Secara matematis, koefisien elastisitas pendapatan inelastis bernilai kurang dari 1 tetapi positif $(0<E<1)$. Hal ini menunjukkan bahwa telur ayam ras merupakan barang normal yaitu apabila telur ayam mengalami kenaikan dalam permintaan sebagai akibat dari kenaikan pendapatan dan secara statistik, besarnya pendapatan berpengaruh nyata terhadap permintaan telur ayam ras tingkat rumah tangga pada taraf nyata $5 \%$. Tanda koefisien elastisitas pendapatan yang positif menunjukkan bahwa apabila kenaikan pendapatan, dalam hal ini semua variabel cateris paribus maka akan di ikuti oleh kenaikan permintaan jumlah telur ayam ras tingkat rumah tangga.

\section{PENUTUP}

\section{Kesimpulan}

1. Faktor-faktor yang mempengaruhi permintaan telur ayam ras di Kecamatan Seruyan Hilir meliputi harga telur ayam ras itu sendiri, harga ikan asin, harga ikan bandeng, harga beras, pendapatan rumah tangga, pendidikan ibu rumah tangga dan jumlah anggota rumah tangga secara simultan berpengaruh nyata terhadap variabel terikat yaitu permintaan telur ayam ras tingkat rumah tangga di Kecamatan Seruyan Hilir. Sedangkan secara individual faktor harga telur ayam ras itu sendiri, harga ikan asin, harga beras, pendapatan dan jumlah anggota keluarga berpengaruh nyata terhadap permintaan telur ayam ras tingkat rumah tangga di Kecamatan Seruyan Hilir. Faktor-faktor lain yaitu harga ikan bandeng dan tingkat pendidikan formal ibu rumah tangga tidak berpengaruh nyata terhadap permintaan telur ayam ras di Kecamatan Seruyan Hilir.

2. Tingkat elastisitas permintaan telur ayam ras di Kecamatan Seruyan Hilir yaitu untuk elastisitas harga bersifat inelastis, dimana suatu kenaikan harga telur ayam ras akan menyebabkan perubahan jumlah yang diminta lebih kecil dari perubahan harga. Besarnya perubahan harga hanya akan memberikan pengaruh yang kecil terhadap perubahan telur ayam yang diminta, sehingga kenaikan harga telur ayam ras yang cukup tinggi sekalipun, permintaan terhadap telur ayam ras tidak terlalu berubah. Nilai koefisien elastisitas harga lebih kecil dari perubahan harganya (Ep= 0,175 ). Untuk elastisitas silang dalam penelitian ini adalah negatif terhadap ikan asin dan beras yang merupakan barang komplementer (pelengkap) dan positif terhadap ikan bandeng yang merupakan barang substitusi (pengganti). Sedangkan elastisitas pendapatan adalah positif yaitu $\mathrm{E}_{\mathrm{I}}=0,843$ menunjukkan bahwa permintaan telur ayam ras merupakan elastisitas pendapatan inelastis artinya perubahan pendapatan sebesar $1 \%$ menyebabkan perubahan permintaan kurang dari $1 \%$. Secara matematis, koefisien elastisitas pendapatan inelastis bernilai kurang dari 1 tetapi positif $(0<E<1)$ sehingga telur ayam ras merupakan barang normal yaitu apabila telur ayam mengalami kenaikan dalam permintaan sebagai akibat dari kenaikan pendapatan.

\section{Saran}

Berdasarkan kesimpulan diatas maka dapat diberikan beberapa saran sebagai berikut :

1. Dengan diperoleh hasil penelitian bahwa telur ayam ras merupakan barang normal yang bersifat inelastis dimana jika terjadi peningkatan harga telur ayam ras maka akan di ikuti penurunan jumlah yang di minta sehingga dalam usaha peningkatan produksi telur ayam ras agar lebih intensif dilakukan karena adanya kecenderungan bahwa permintan rumah tangga terhadap 


\section{A MIMBAR \\ ISSN 2460-4321}

Volume 1・ Nomor 1・Juli 2015

telur ayam ras akan bertambah dengan adanya peningkatan pendapatan.

2. Dengan diperoleh hasil penelitian bahwa ikan bandeng merupakan barang substitusi dari telur ayam ras, dimana hal ini menunjukkan bahwa konsumen akan beralih pada komoditi yang harganya relatif murah sehingga untuk meningkatkan konsumsi telur ayam ras per kapita di Kecamatan Seruyan Hilir perlu adanya standarisasi harga telur ayam ras yang selama ini belum dilakukan. Hal ini dimaksudkan untuk menjaga kestabilan harga telur ayam ras yang setiap tahun cenderung mengalami fluktuasi. Dengan adanya usaha ini maka diharapkan apabila terjadi perubahan pada harga telur ayam ras tidak akan secara dratis merubah jumlah konsumsi telur ayam ras yang dikonsumsinya, karena dengan adanya substitutan maka harga telur ayam ras meningkat,sehingga konsumen cenderung beralih kepada substitutan tersebut, walaupun pada kenyataannya secara nominal harga substitutan tersebut relatif mahal tetapi secara riil relatif murah dibanding harga telur ayam ras .

3. Dengan diperoleh hasil penelitian bahwa ikan asin dan beras merupakan barang komplementer bagi telur ayam ras dan jumlah anggota keluarga berpengaruh terhadap permintaan telur ayam ras, maka perlu dilakukan peningkatan produksi telur ayam ras secara terus menerus, karena disamping telur ayam ras sebagai kebutuhan lauk pauk dan pelengkap kebutuhan untuk pembuat makanan, telur ayam ras juga merupakan kebutuhan pangan sebagai pemenuh sumber protein hewani bagi setiap angota keluarga karena semakin banyak jumlah anggota keluarga akan semakin banyak jumlah konsumsi telur ayam ras yang dibutuhkan.

4. Bagi peneliti lain yang berminat mengembangkan penelitian ini, perlulah dikaji lebih lanjut selera masyarakat terhadap telur ayam ras sehingga pengembangan data tidak hanya pada konsumsi rumah tangga biasa, tetapi juga pada rumah tangga khusus, selain itu untuk pengembangan lebih lanjut perlu pula dilakukan penelitian mengenai grading terhadap kualitas telur ayam ras yang dihasilkan.

\section{DAFTAR PUSTAKA}

Boediono. (2002). Ekonomi Mikro, Seri Sinopsis Pengantar Ilmu Ekonomi Nol. Edisi kedua. BPFE. Yogyakarta.

Daniel, M. (2004). Pengantar Ekonomi Pertanian cetakan kedua. Bumi Aksara. Jakarta.

Daniel, M. (2005). Metode Penelitian Sosial Ekonomi, cetakan ketiga. Bumi Aksara. Jakarta.

Ghozali, Imam. (2006). Aplikasi Analisis Multivariate Dengan Program SPSS. Badan Penerbit Universitas Diponegoro. Semarang.

Gujarati, Damodar. (2009). Dasar-dasar ekonometrika. Jilid I. Erlangga. Jakarta.

Hanafie, R. (2010). Pengantar Ekonomi Pertanian. CV Andi Offset. Yogyakarta.

Imans, S. (2010). Analisis permintaan telur ayam ras tingkat rumahtangga di kota Banjarbaru Kalimantan Selatan. Tesis Program Pasca Sarjana Ekonomi Pertanian - Unlam. Banjarbaru.

Iriawan, Nur \& Astuti, Septian Puji. (2006). Mengolah data statistik dengan mudah menggunakan minitab 14. ANDI. Yogyakarta.

Juanda. (2009). Ekonometrika : Pemodelan dan Pendugaan. IPB Press. Bogor.

Kantor Administrasi Pelabuhan Kuala Pembuang. (2011). Database Administrasi Pelabuhan Kuala Pembuang. Kabupaten Seruyan.

Kantor Ketahanan Pangan Kabupaten Seruyan. (2011). Database Ketahanan Pangan Kalimantan Tengah. Kabupaten Seruyan.

Lipsey R.G, Steiner, Peter O, Puevis, dan Douglas D. (1992). Pengantar Mikro Ekonomi,edisi kedelapan Jilid 1.Erlangga. Jakarta A.Jaka Wasana dan Kirbrandoko (Alih Bahasa).

Mankiw, N, Gregory. (2002). Pengantar Ekonomi.Erlangga. Jakarta.

Raharja dan Mandala. (2002). Teori Ekonomi Mikro; Suatu Pengantar. Fakultas Ekonomi Universitas Indonesia. Jakarta.

Rahim dan Diah retno. (2007). Ekonomika Pertanian; Pengantar, teori dan kasus. Penebar Swadaya. Jakarta. 
Rasyaf, M. (1991). Pengelolaan Produksi Telur. Fakultas Peternakan IPB. Bogor.

Setiawan. (2007). Penentian ukuran sampel memakai rumus Slovin dan tabel KrejcieMorgan : Telaah konsep dan aplikasinya. Skripsi program sarjan Fakultas Peternakan Universitas Padjadjaran. Bandung.

Soekartawi. (2002). Prinsip Dasar Ekonomi Pertanian: Teori dan Aplikasi. Edisi Revisi 2002, Raja-Grafindo Persada, Jakarta.

Soetriono, dkk. (2003). Pengantar Ilmu Pertanian. Universitas Jember Fakultas pertanian, Jember.

Sudjana. (1992). Metode Statistika, Edisi keenam. Penerbit Tarsito. Bandung.

Sukirno S. (2006). Makroekonomi Teori Pengantar Edisi ketiga. PT RajaGrafindo Persada, Jakarta.

Supranto, J. (2000). Teknik sampling untuk survey dan eksperimen . PT Rineka Cipta. Jakarta.

Veronika, H,S. (2008). Faktor-faktor yang mempengaruhi perilaku konsumen terhadap permintaan telur ayam kampung. Skripsi Program sarjana Sosial Ekonomi Pertanian- Universitas Sumatera Utara.

Wahyuningsih,R. (2008). Analisis permintaan telur ayam di Jawa Timur. Skripsi Program Sarjana Fakultas PertanianUniversitas Muhammadiyah Jember. 


\section{MIMBAR Agribisnis ISSN 2460-432I \\ Volume 1・Nomor 1 • Juli 2015}

